\title{
DAMPAK SOSIAL EKONOMI PEMBANGUNAN BANDARA INTERNASIONAL YOGYAKARTA BAGI MASYARAKAT PURWOREJO
}

\author{
Annisa Fitri Nurkholidah dan Poerwanti Hadi Pratiwi \\ Pendidikan Sosiologi, Fakultas IImu Sosial, Universitas Negeri Yogyakarta \\ Email : annisafnk@gmail.com
}

\begin{abstract}
Abstrak
Penelitian ini bertujuan untuk mengetahui dampak sosial ekonomi pembangunan Bandara Internasional Yogyakarta bagi masyarakat Purworejo. Penelitian ini merupakan jenis penelitian kualitatif dengan pendekatan deskriptif dengan menggunakan metode purposive sampling. Validasi data yang digunakan yaitu teknik triangulasi sumber.Teknik pengumpulan data yang digunakan adalah observasi, wawancara, dan dokumentasi. Teknik analisis yang digunakan adalah model Miles and Huberman yang meliputi pengumpulan data, reduksi data, penyajian data dan menarik kesimpulan/verivikasi. Hasil penelitian menunjukkan bahwa pembangunan Bandara Internasional Yogyakarta berdampak positif dalam aspek sosial yaitu peningkatan pola pikir masyarakat terhadap pendidikan seperti perubahan pola pikir masyarakat terhadap pendidikan anak dan meningkatnya kualitas SDM masyarakat. Sedangkan dalam aspek ekonomi yaitu peningkatan pendapatan yang disebabkan oleh faktor pekerjaan dan meningkatnya potensi pariwisata. Keberadaan Bandara YIA juga berdampak negatif pada aspek lingkungan sosial seperti penipuan, masuknya budaya asing, dan meningkatnya kriminalitas serta meningkatnya pengeluaran masyarakat.
\end{abstract}

Kata Kunci: Bandara YIA, Dampak Sosial Ekonomi, Purworejo

Abstract

This research is aimed to know social economics impacts of the Yogyakarta International Airport construction on the Purworejo society. It is a qualitative research with a descriptive approach. There are 10 interviewees who are choosen by purposive sampling methods. Data validation used is the source triangulation technique. The data collecting techniques used are observation, interview, and documentation. Moreover, the data analysis techniques used is Miles and Huberman's model which is consist of collecting of the data, reduction of the data, presentation of the data, and drawing a conclusion/ verivication. The result of the research shows that the Yogyakarta International Airport construction has positive impacts in the social aspect. Those are the improvement of people's mindset toward an education such as the change of people's mindset toward children educations and the improvement of human resources. While in the economic aspect, there are an improvement of the people's income which is caused by job factors, and an improvement of tourism potential. The existence of Yogyakarta International airport, on the other hand, has negative impacts on the social environment aspect such as a deception, the entering of foreign culture, and the increasing of criminalities. Furthermore, it also has an impact on the economic aspect such as the people's outcome is increase.

Keywords: Yogyakarta International Airport, Socio-economic impact, Purworejo

\section{Pendahuluan}

Perkembangan suatu wilayah dapat terwujud apabila didukung oleh tersedianya sarana dan prasarana seperti jalan raya, terminal, listrik, pelabuhan laut dan bandara. Keberadaan infrastruktur memiliki peran yang sangat vital dalam mewujudkan interaksi sosial dan kelangsungan sistem perekonomian suatu wilayah. Apabila semakin baik keadaan infrastruktur, maka semakin baik pula pengaruhnya terhadap interaksi sosial dan keadaan ekonomi suatu wilayah serta dapat memicu kemajuan dan perkembangan suatu wilayah 
(Zulfikar, 2017). Hal tersebut dimungkinkan, karena sarana dan prasarana transportasi berfungsi sebagai pembentuk, pengarah, dan pemicu pertumbuhan suatu wilayah. Dengan fungsi yang demikian maka dapat dilihat sejauh mana efektivitas penggunaan lahan suatu wilayah, serta intensitas dan frekuensi pergerakan sosial ekonomi masyarakat.

Pertumbuhan

penduduk yangmeningkat diiringi dengan aktivitas kehidupan sehari-hari yang kian bertambah,menyebabkan fasilitas umum dirasakan belum mencukupi. Usaha pemerintah mengurangi kemiskinan dengan

meningkatkanpertumbuhanekonomi masyarakat dipedesaan melalui pembangunan infrastruktur. Pembangunan merupakan suatu hal yang digunakan untuk menjelaskan proses dan usaha untuk meningkatkan kehidupan ekonomi, politik, budaya, infrastruktur masyarakat dan sebagainya yang tertuju padaperubahan dalam masyarakat (Fakih,2002: 12-13).

Pembangunan infrastruktur adalah suatu fenomena perubahan sosial dimasyarakat yang berasal dari perubahan lingkungan. Salah satu transportasi yang saat ini terus berkembang dan menjadi perhatian adalah transportasi udara. Indonesia merupakan salah satu negara di Asia yang mengalami peningkatan jumlah penumpang transportasi udara yang cukup drastis selama tahun 1990-an, diikuti oleh Malaysia (Chang, 2010 : 56). Dengan meningkatnya jumlah penumpang transportasi udara, maka dilakukan pengembangan bandara untuk dapat memenuhi kebutuhan penumpang. Menurut Salindri (2016 : 83) adanya suatu bandara memiliki pengaruh atau dampak yang besar terhadap pertumbuhan ekonomi. Bandara menjadi salah satu penggerak roda perekonomian seiring dengan semakin pesatnya mobilitas masyarakat.

\section{Menurut Peraturan Pemerintah} Republik Indonesia Nomor 40 Tahun 2012,Bandara merupakan suatu unsur yang memiliki peranan penting dalampenyelenggaraan penerbangan dengan selamat, aman, lancar, tertib, nyaman, dan berdayaguna, serta dapat berperan dalam hal pemerataan, pertumbuhan, dansebagai pendorong maupun penggerak untuk menunjang pembangunan nasional. Selain itu, perkembangan wilayah terutama kawasan sekitar bandara memiliki pertumbuhan yang relatif berkembang lebih cepat jika dibandingkan dengan wilayah lainnya. Hasil riset Aryany (2014 : 96) menunjukkan bahwa keberadaanBandara Internasional Kualanamu di Kabupaten Deli Serdang telah memberikan perubahan aktivitas penggunaan lahan, kondisi sosial ekonomi masyarakat, dan perubahan nilai lahan kawasan sekitarnya. Perubahan tersebut karena didukung oleh pembangunan 
infrastruktur pendukung kegiatan bandara di beberapa kawasan tertentu, sehingga kawasan sekitarnya menjadi daya tarik para investor untuk menanamkan modalnya di kawasan tersebut.

Pembangunan bandara YIA merupakan suatu pembangunan yang bersifat mendesak dan diperuntukkan bagi kepentingan umum. Dengan keadaan yang mendesak tersebut maka keberadaan bandara sangat diperlukan untuk menunjang peningkatan sosial dan ekonomi di Daerah Istimewa Yogyakarta dan wilayah penerima dampak lainnya. Kebijakan pembangunan Bandara Internasional Yogyakarta di Kabupaten Kulonprogo resmi dimulai pada 27 Januari 2017. Dimulainya pembangunan bandara lahan seluas 587 hektar ditandai dengan prosesi "Babat Alas Nawung Kridha" berupa peletakan batu merah oleh Presiden Joko Widodo pada hari Jumat 27 Januari 2017 di Desa Jangkaran, Kecamatan Temon Kabupaten Kulonprogo, Daerah Istimewa Yogyakarta (Publik, 2017). Pembangunan bandara YIA dilakukan untuk menggantikan peran bandara Adisutjipto yang kapasitasnya sudah tidak mampu lagi untuk menampung jumlah pergerakan pesawat yang ada. Pengembangan bandara di Adisutjipto pun sudah tidak dapat dilakukan karena keterbatasan lahan.

Pihak Pemerintah melakukan studi kelayakan untuk merelokasi bandara Adisutjipto di daerah Kecamatan Temon,
Kabupaten Kulonprogo. Adapun dasar hukum pembangunan bandara YIA yaitu Perda Nomor 1 tahun 2012 tentang RTRW (Rencana Tata Ruang dan Wilayah) Kulonprogo tahun 2012-2032 yang dilengkapi dengan Undang-Undang No 2 Tahun 2012 tentang Pengadaan Tanah bagi pembangunan untuk kepentingan umum. Surat keputusan Gubernur DIY No.68/KEP/2015 dan putusan kasasi Mahkamah Agung No.456K/TUN/2015 (Pemerintah Daerah DIY, 2016).

Pembangunan Bandar Udara dimanapun lokasinya pada umumnya akanmenjadi magnet pembangunan disekitarnya, maka akan jauh lebih baik jika wilayah tersebut sejak dini telah mempunyai perencanaan yang baik untukmengantisipasi kemungkinan yang terjadi sehingga pembangunan tersebut akanlebih terarah dan terkendali menjadi pola yang teratur sebagai pintu gerbangpeningkatan ekonomi wilayah tersebut dan sekitarnya. Karena pada hakikatnya, tidak ada satupun wilayah di permukaan bumi yang dapat berdiri sendiri hanya dengan mengandalkan sumber daya yang dimilikinya (Yunus, 2011). Oleh karena itu, menjadi hal yang wajar bila suatu wilayah menerima multiplayer effect di wilayah lain untuk memenuhi pemenuhan kebutuhan para penduduknya.

Keberadaan YIA di Kecamatan Temon berpotensi melahirkan multiplayer effect baik positif maupun negatif bagi 
Kulonprogo dan Purworejo, Jawa Tengah yang notabene merupakan wilayah paling dekat dengan bandara (Dewantara, 2019). Letak geografis suatu wilayah memiliki peran penting dalam kaitannya dengan wilayah lain, baik dalam aktivitas ekonomi, sosial, maupun politik. Oleh karena itu, pengembangan ekonomi dan politik yang kokoh pada suatu wilayah, khususnya melalui berbagai macam pembangunan infrastruktur akan memberikan pengaruh keberhasilan pembangunan di wilayah yang bersangkutan maupun wilayah di sekitarnya (Zulfikar, 2017). Berdasarkan letak geografisnya, Bandara Internasional Yogyakarta sebelah barat berbatasan langsung dengan Kabupaten Purworejo.

Kabupaten Purworejo merupakan daerah agraris dan menjadi salah satu penyangga pangan di Provinsi Jawa Tengah dengan hasil utama seperti padi, kedelai, dan jagung. Selain menjadi kota penyangga pangan, Purworejo juga menjadi kota pendukung utama bandara Kulonprogo. Hal tersebut dikarenakan Purworejo mendapatkan multiplayer effect adanya bandara YIA, terlebih jarak antara Kulonprogo lebih dekat dengan Purworejo dibandingkan menuju Daerah Istimewa Yogyakarta yaitu hanya berjarak sekitar 7 km. Lokasi Bandara Yogyakarta International Airport di wilayah Kecamatan Temon, Kabupaten Kulonprogo, DIY dan sangat dekat dengan wilayah Kabupaten Purworejo yang hanya dibatasi oleh aliran Sungai Bogowonto. Lokasi YIA ada di sebelah timur sungai, sedangkan Desa Jogoboyo yang sudah masuk wilayah Kecamatan Purwodadi, Kabupaten Purworejo di sebelah barat sungai (Yosodipuro, 2018). Secara geografis, hal tersebut tentu saja merupakan bonus positif untuk mengembangkan wilayah Purworejo (Saputra, 2018).

Pemerintah Kabupaten Purworejo mengambil tindakan awal dengan melakukan sosialisasi yang mengajak masyarakat berdiskusi untuk mempersiapkan segala bentuk dampak dari adanya YIA yang bertujuan agar masyarakat Purworejo ikut terlibat dalam menangkap peluang adanya bandara YIA. Selain itu, Bupati Purworejo telah melakukan kerjasama dengan Pemkab Kulonprogo di bidang pemerintahan, yang meliputi pembangunan dan kemasyarakatan yang dapat membangun kerjasama di wilayah perbatasan Purworejo - Kulonprogo. Oleh karena itu Purworejo akan menjadi penerima dampak adanya bandara YIA Kulonprogo.

Kehidupan sosial ekonomi masyarakat Purworejo dapat dipengaruhi oleh keberhasilan pembangunan bandara YIA di Kulonprogo yang menjadikannya suatu dampak positif yang menguntungkan. Penyiapan infrastruktur di Purworejo baik jalan maupun jembatan menjadi satu fokus kegiatan yang tidak dapat dipisahkan. Hal tersebut menarik perhatian utama bagi investor asing yaitu menjadikan Wilayah Selatan Kabupaten 
Purworejo menjadi lokasi strategis untuk pengembangan bisnis (Heksantoro, 2018). Beberapa proyek strategis nasional yang dilakukan di Purworejo menjadi kegiatan yang amat prestisius (Agung, 2018).

Kebijakan pembangunan Bandara Internasional Yogyakartasebagai salah satu bentuk pembangunan infrastruktur yang dapat memberikan peluang bagi wilayah terdampak. Dalam hal ini, Purworejo termasuk dalam wilayah yang terdampak karena jarak antara Bandara Kulonprogo dengan Purworejo hanya $\pm 7 \mathrm{~km}$. Selain itu, adanya harapan mengembangkan segala potensi yang dimiliki Kabupaten Purworejo, harapan Purworejo menjadi kota penyangga utama dengan adanya bandara YIA akan menjadi sesuatu hal yang menarik untuk diadakan penelitian apakah dampak yang akan diterima masyarakat Kabupaten Purworejo dalam bidang sosial ekonomi dengan adanya Bandara YIA. Dari latar belakang inilah yang menarik peneliti untuk mengetahui dampak sosial ekonomi yang akan terjadi dengan adanya Pembangunan YIA bagi Purworejo. Dan dengan demikian peneliti akan melakukan penelitian yang berjudul "Dampak Sosial Ekonomi Pembangunan Bandara Internasional Yogyakarta Bagi Masyarakat Purworejo".

\section{Metode}

Penulisan dalam penelitian ini menggunakan metode penelitian kualitatif.
Jenis penelitian yang dilakukan dalam penelitian ini adalah penelitian kualitatif deskriptif. Kualitatif deskriptif merupakan penelitian yang memberikan gambaran secara cermat mengenai individu atau kelompok tertentu tentang keadaan dan gejala yang terjadi. Lokasi yang dipilih dalam penelitian ini adalah Desa Dadirejo Kecamatan Bagelen dan Desa Jogoboyo Kecamatan Purwodadi. Alasan peneliti mengambil lokasi tersebut merupakan Desa di Purworejo yang berbatasan langsung dengan kawasan YIA. Meskipun Purworejo tidak secara langsung terlibat dalam pembangunan bandara YIA namun, Purworejo diharapkan mampu menjadi kota penyangga dari bandara YIA, hal tersebut didukung oleh lokasi geografis antara Bandara YIA dengan Purworejo hanya berjarak sekitar $7 \mathrm{~km}$.

Penelitian terkait dampak pembangunan YIA (Yogyakarta International Airport) terhadap kondisi sosial ekonomi Kabupaten Purworejo ini dilakukan pada bulan Desember 2019 hingga Januari 2020 di Purworejo. Kriteria dalam subyek penelitian ini antara lain (1) Dinas Pariwisata dan Dinas Perindustrian dan Tenaga Kerja Kabupaten Purworejo. (2) Pimpinan Kecamatan Purwodadi dan Kecamatan Bagelen, (3) Perangkat Desa Dadirejo dan Jogoboyo. (4) Warga yang berdomisili minimal 5 tahun di Desa Dadirejo Kecamatan Bagelen dan Desa Jogoboyo Kecamatan Purwodadi, (5) mengetahui pembangunan bandara YIA 
Kulonprogo. Data dalam penelitian ini menggunakan data primer yang diperoleh hasil wawancara bersumber dari responden yang sesuai dengan kriteria. Serta menggunakan data sekunder yang berupa buku-buku, literature artikel, jurnal, studi kepustakaan baik media cetak maupun internet.

Adapun teknik pengumpulan data yang digunakan penulis dalam penelitian ini adalah observasi, wawancara, studi pustaka, dan dokumentasi. Teknik pengambilan sampel pada penelitian ini adalah purposive sampling. Peneliti menggunakan triangulasi sebagai uji kevalidan data. Teknik triangulasi diartikan sebagai teknik pengumpulan data yang bersifat menggabungkan dari berbagai teknik pengumpulan data dan sumber data yang telah ada (Sugiyono, 2013: 373). Dalam penelitian ini akan dilakukan menggunakan triangulasi sumber yang berarti membandingkan dan mengecek ulang derajat kepercayaan suatu informasi yang diperoleh melalui sumber waktu dan alat yang berbeda dalam penelitian kualitatif (Moleong, 2014 : 330). Hal tersebut dapat dicapai dengan cara membandingkan hasil wawancara dengan dokumen yang ada, serta membandingkan apa yang dikatakan umum dengan apa yang dikatakan secara pribadi. Triangulasi sumber yang dipakai yaitu membandingkan data hasil wawancara pada setiap masyarakat yang sesuai dengan kriteria penelitian dengan isi dokumen yang terkait.

Teknik analisis data dalam penelitian ini menggunakan teknik analisis data yang yang terdiri dari tiga aspek (Miles dan Huberman, 2009: 16), yaitu: Reduksi data, penyajian data, dan penarikan kesimpulan atau verivikasi.

\section{Hasil dan Pembahasan}

\section{Dampak sosial Pembangunan Bandara Internasional Yogyakarta bagi Masyarakat Purworejo}

a. Dampak Positif

Adanya bandara YIA di Kulonprogo berdampak pada perubahan pola pikir masyarakat terhadap pendidikan. Harga tanah di Wilayah Purworejo menjadi tinggi. Tanah yang awalnya hanya lahan kosong, saat ini menjadi sesuatu hal yang memiliki harga jual tinggi. Untuk Kecamatan Purwodadi dan Bagelen sebagai kecamatan yang berbatasan langsung dengan Kulonprogo tentu saja menjadi sasaran utama para investor untuk membeli tanah di wilayah tersebut sebagai daerah perindustrian. Hal tersebut mengakibatkan perubahan pola pikir masyarakat bahwa lahan di Kecamatan Bagelen dan Purwodadi berpotensi untuk dijual dengan harga tinggi sehingga pendapatan bertambah. Penghasilan masyarakat bertambah sehingga tingkat pendidikan masyarakat pun semakin meningkat. Berdasarkan data dari informan bahwasanya terdapat beberapa 
hal peningkatan pola pikir masyarakat terhadap pendidikan, diantaranya adalah;

1) Perubahan Pola Pikir Masyarakat terhadap Pendidikan Anak

Pendidikan masyarakat Purworejo beragam, tidak dapat dikatakan tingkat mayoritas dan minoritas. Akan tetapi berdasarkan data desa Jogoboyo dan Dadirejo sebagai lokasi penelitian, mayoritas pendidikannya adalah SMA/Sederajat. Namun semenjak adanya bandara YIA pada tahun 2018 masyarakat Jogoboyo dan Dadirejo sudah sangat sadar akan pentingnya pendidikan. Bahkan 5 dari 6 narasumber masyarakat Desa Jogoboyo dan Dadirejo mengatakan bahwa saat ini pendidikan adalah suatu hal yang sangat penting dan akan menjadi bekal utama kehidupan seseorang. Terlebih beberapa tahun ke depan Kabupaten Purworejo akan lebih maju, ramai dan berbeda dibandingkan tahuntahun sekarang karena adanya bandara YIA. Hal tersebut berdampak pada perubahan tingkat pendidikan Kabupaten Purworejo khususnya masyarakat Desa Jogoboyo dan Dadirejo. Pasca pembangunan bandara YIA pola pikir masyarakat di Desa Jogoboyo dan Dadirejo berubah mengarah ke kemajuan dan orientasi ke masa depan untuk memperbaiki keturunannya. Dengan demikian jika melihat model pertumbuhan Rostow yang dikutip oleh Budiman (2000 : 26) dalam konsep pembangunan, dapat dikatakan bahwa intervensi pemerintah
Purworejo adanya pembangunan Bandara YIA membuat masyarakat di Desa Jogoboyo dan Dadirejo ini menjadi masyarakat yang naik level menjadi masyarakat pra kondisi lepas landas. Masyarakat Jogoboyo dan Dadirejo memanfaatkan harga tanah yang tinggi untuk dapat menyekolahkan anak nya ke jenjang yang lebih tinggi. Dengan adanya bandara YIA masyarakat di Dadirejo memiliki keinginan untuk dapat bekerja di bandara dan berupaya untuk meningkatkan pendidikannya agar memiliki skill yang di butuhkan.

2) Meningkatnya Kualitas SDM Masyarakat

Dampak positif di bidang pendidikan yaitu masyarakat di Desa Jogoboyo dan Dadirejo mendapatkan training, workshop dan sosialisasi kepada masyarakat dalam rangka membangun SDM berkualitas dan mempersiapkan IKM yang dilakukan oleh Dinas Perindustrian dan Tenaga Kerja Kabupaten Purworejo. Adanya intervensi pemerintah dalam pembangunanmengakibatkan sedikit kemajuan pada wawasan dan pengetahuan masyarakat yang tadinya tidak tahu menjadi tahu. Selain itu, jika melihat pada dampak social pembangunan infrastruktur secara langsung juga dapat mempengaruhi perubahan sosial seperti yang diungkapkan oleh Soekanto (2012:20) bahwa pendidikan yang maju dan berorientasi pada masa depan juga 
menjadi faktor pendorong dalam perubahan sosial yang ada di Desa Jogoboyo Kecamatan Purwodadi dan Desa Dadirejo Kecamatan Bagelen Kabupaten Purworejo.

b. Dampak Negatif

Dampak terhadap Lingkungan Sosial

$\begin{array}{cr}\text { Pembangunan } & \text { Bandara } \\ \text { Internasional } \quad \text { Yogyakarta } & \text { banyak }\end{array}$
memberikan dampak pada masyarakat walaupun dampak tersebut bermacammacam modelnya mulai dari yang baik maupun tidak baik. Adanya bandara Internasional Yogyakarta berdampak pada penambahan jumlah penduduk di sekitar kawasan bandara YIA. Desa Jogoboyo dan Desa Dadirejo merupakan penerima dampak penambahan penduduk karena adanya pekerja bandara YIA. Hal signifikan lain yang tidak kalah penting adalah menjadi daerah rawan kriminalitas. Keberadaan Bandara YIA juga membawa pengaruh yang tidak baik bagi penduduk asli Jogoboyo dan Dadirejo sebagai wilayah terdampak. Dengan banyak pekerja bandara YIA yang tinggal di wilayah terdampak tersebut maka banyak budaya baru yang masuk, terjadi penipuan, pencurian dan menjadi daerah rawan kriminalitas. Banyak dampak negatif untuk lingkungan sosial di wilayah terdampak bandara YIA.

Adanya bandara YIA juga berdampak negatif untuk lingkungan sosial wilayah terdampak bandara YIA seperti Desa Jogoboyo dan Dadirejo. Menurut
Susanto (1997:157) perubahan sosial terjadi akibat adanya beberapa faktor yang mempengaruhi, yaitu ilmu pengetahuan, kemajuan teknologi serta penggunannya oleh masyarakat, komunikasi, perubahan atau peningkatan harapan dan tuntutan manusia. Perubahan sosial dapat menjadi kemajuan dan kemunduran bagi masyarakat. Kemunduran pada masyarakat dalam hal ini dibuktikan dengan beberapa dampak negatif yang sudah terjadi yaitu warung makan di wilayah terdampak menjadi korban penipuan para pekerja bandara YIA, Desa Jogoboyo menjadi rawan kriminalitas, pencurian kemudian hal lain yaitu munculnya mafia tanah dan sengketa tanah. Kemudian beberapa dampak yang kemungkinan akan terjadi yaitu pengaruh budaya asing yang kurang baik akan mudah ditiru oleh generasi penerus, dan menjadi daerah pengguna narkoba.

2. Dampak Ekonomi Pembangunan Bandara Internasional Yogyakarta bagi Masyarakat Purworejo

a. Dampak Positif

Pembangunan dilakukan untuk meningkatkan taraf hidup yang sering kali diukur tinggi rendahnya pendapatan dan dan meningkatnya produktivitas. Bandara merupakan pusat kegiatan yang memiliki daya tarik sehingga memicu perubahan dan perkembangan kawasan sekitar bandara (Kasarda \& Lindsay, 2011). Masyarakat merupakan suatu realitas yang di dalamnya terjadi proses interaksi 
sosial dan terdapat pula pola interaksi. Hubungan antara ekonomi dan masyarakat, termasuk didalamnya ada proses dan pola interaksi bersifat saling mempengaruhi atau timbal balik. Masyarakat selalu berubah sesuai dengan keadaan lingkungannya antara kelompok masyarakat yang satu dengan yang lain terdapat perubahan yang berbeda.

Dengan adanya bandara YIA di Kulonprogo sangat berdampak untuk pendapatan masyarakat di Purworejo yang berbatasan langsung dengan Kabupaten Kulonprogo yaitu Desa Jogoboyo dan Desa Dadirejo. Dampak yang didapatkan yaitu mengenai perubahan pendapatan rumah tangga mengalami peningkatan. Meskipun masih ada juga yang tetap pada tingkat pendapatan awal sebelum ada bandara YIA. Keadaan tersebut dipengaruhi oleh masyarakat menangkap peluang usaha yang ada. Berdasarkan data dari informan bahwasanya terdapat beberapa faktor yang menyebabkan mengalami peningkatan pendapatan, diantaranya adalah ;

1) Faktor Pekerjaan

Keberadaan bandara YIA membuat penduduk yang aktif dan kreatif mempunyai pekerjaan yang baru yang juga berpengaruh pada peningkatan pendapatan. Sedangkan bagi penduduk yang kurang aktif dan kreatif dalam menyiasati keadaan tidak berpengaruh terhadap pendapatan. Perubahan sosial merupakan konsekuensi utama dari proses modernisasi yang dialami suatu masyarakat (Shahab, Sosiologi Perdesaan, 2013). Proses modernisasi tersebut berdampak pada cara berfikir yang terbuka agar dapat memanfaatkan peluang yang ada di sekitarnya. Peningkatan pendapatan tersebut dikarenakan masyarakat yang mampu menangkap peluang usaha dengan baik. Setelah dibangun Bandara Internasional Yogyakarta, dapat mengurangi angka pengangguran di Kabupaten Purworejo. Khususnya di wilayah yang berbatasan langsung dengan kawasan bandara YIA memiliki pekerjaan tetap dan penghasilan setiap bulan karena dapat bekerja dalam proses pembangunan bandara walaupun sebagai tenaga kasar, sopir dan ada juga yang membuka usaha warung makan, menyediakan kost/kontrakan, menjadi agen gas LPG, dan lainnya. Dalam perspektif makroekonomi, indikator pendapatan perkapita merupakan bagian kesejahteraan manusia yang dapat diukur, sehingga dapat menggambarkan kesejahteraan dan kemakmuran masyarakat.

2) Peningkatan Potensi Pariwisata Keberadaan Bandara Internasional Yogyakarta (YIA) di Kulonprogo merupakan sebuah anugerah untuk Kabupaten Purworejo karena berada di perbatasan dengan Kabupaten Purworejo yang hanya berjarak $\pm 7 \mathrm{~km}$. Hal tersebut memacu Pemerintah Daerah Kabupaten Purworejo untuk membenahi diri terutama 
di sektor pariwisata. Menurut Arsyad (1999) pembangunan ekonomi daerah adalah suatu proses dimana pemerintah daerah dan masyarakat mengelola sumber daya yang ada dan membentuk suatu pola kemitraan antara pemerintah daerah dengan sektor swasta untuk menciptakan suatu lapangan kerja baru dan merangsang perkembangan kegiatan ekonomi dalam wilayah tersebut.

Maka dengan adanya bandara YIA memunculkan beberapa pariwisata baru di Kabupaten Purworejo agar dapat menarik wisatawan baik dari dalam maupun luar negeri. Beberapa pariwisata unggulan Kabupaten Purworejo antara lain Glamping De Loano, Bukit Besek, Goa Seplawan, Wisata GunungKunir, Taman Air Sidandang, Puncak Khayangan Sigendol, Curug Lumbung dan masih banyak lainnya. Selain obyek wisata yang bertambah juga pengunjung wisatawan Purworejo mengalami peningkatan setiap tahunnya. Progress kunjungan wisatawan menuju Purworejo meningkat setiap tahunnya, hal tersebut dapat berdampak pada perekonomian masyarakat sekitar.Semenjak adanya bandara YIA kini semakin banyak obyek wisata di daerah Purworejo yang nantinya bertujuan untuk meningkatkan perekonomian masyarakat tersebut. Meskipun sebaran potensi obyek wisata di Kabupaten Purworejo tinggi namun masih perlu dibenahi terkait sarana dan prasarana. Semakin banyaknya sebaran potensi obyek wisata di Purworejo menunjukkan adanya pengembangan kreativitas oleh masyarakat Purworejo. Budiman (1995:13) mengungkapkan pembangunan tidak hanya berurusan dengan produksi dan distribusi barang material tetapi juga harus menciptakan kondisi-kondisi yang mendukung manusia untuk merasa aman, bahagia, dan dapat mengembangkan kreativitasnya.

b. Dampak Negatif

1) Pengeluaran bertambah

Pembangunan Bandara Internasional Yogyakarta memberikan dampak pada sikap dan perilaku masyarakat tentu juga berdampak pada pengeluaran yang disebabkan meningkatnya pendapatan masyarakat Purworejo terdampak. Pengeluaran berlebih dilakukan oleh masyarakat untuk biaya pendidikan, membeli kebutuhan tersier seperti mobil, membangun kostkost an, membangun tempat usaha selain itu juga dikarenakan harga tanah yang tinggi sehingga berdampak pada pajak tanah yang tinggi pula. Semenjak adanya bandara YIA berakibat pada kenaikan upah yang harus diberikan kepada pekerja sama rata dengan upah pekerja di bandara YIA. BS mengungkapkan semenjak adanya Bandara YIA upah pekerja hariannya mencapai 80-100 ribu dari yang awalnya hanya 50 ribu. Dan juga pengeluaran untuk harga pajak tanah di sekitar wilayah Jogoboyo sangat meningkat, hal tersebut terjadi karena 
harga tanah yang tinggi semenjak adanya bandara YIA.

\section{Sumarwan}

(2004:57) mengungkapkan bahwasanya gaya hidup seseorang biasanya tidak permanen dan cepat berubah menyesuaikan dengan perubahan hidupnya. Berdasarkan narasumber dapat disimpulkan perubahan hidup yang terjadi di Masyarakat Purworejo terdampak bandara YIA yaitu pengeluaran yang bertambah. Pengeluaran tersebut dalam bentuk biaya pendidikan untuk meningkatkan taraf pendidikan anaknya agar mampu menguasai skill bekerja di bandara YIA, membangun usaha, membangun kost/kontrakan, dan juga harga pajak tanah yang semakin tinggi. Selain itu pengeluaran yang bertambah juga disebabkan karena meningkatnya upah pekerja yang harus diberikan setaraf dengan pekerja di bandara YIA.

\section{Simpulan}

Berdasarkan rumusan masalah yang dianalisis dalam penelitian ini, maka dapat ditarik kesimpulan bahwa Bandara Internasional Yogyakarta berdampak bagi masyarakat Purworejo. Khususnya untuk Desa Jogoboyo Kecamatan Purwodadi dan Desa Dadirejo Kecamatan Bagelen. Hasil penelitian menunjukkan peluang usaha di daerah perbatasan DIY Purworejo yaitu Desa Jogoboyo dan Desa Dadirejo termasuk dalam kategori tinggi. Masyarakat sekitar memanfaatkan situasi ini untuk berdagang, menyediakan kost/kontrakan, hingga membangun toko. Pembangunan Bandara YIA berhasil menyerap banyak tenaga kerja. Tidak hanya tenaga kerja dalam proses pembangunan bandara, namun juga terjadi kenaikan omset penjualan yang dialami para pedagang di sekitar bandara khususnya di Wilayah Purworejo. Lambat laun jumlah pengangguran di sekitar wilayah Purworejo yang berbatasan dengan bandara YIA mulai menurun. Penurunan jumlah pengangguran dan peningkatan pendapatan masyarakat berdampak positif bagi kondisi sosial ekonomi masyarakat sekitarnya. Peningkatan pendapatan di kawasan perbatasan DIY dan Purworejo juga dipengaruhi oleh harga tanah yang tinggi. Karena harga tanah tinggi maka banyak tanah di wilayah Dadirejo dan Jogoboyo dijual.Pembangunan Bandara YIA juga berdampak pada peningkatan pola pikir masyarakat terhadap pendidikan di wilayah tersebut. Banyak warga yang menjual tanahnya agar dapat menyekolahkan anaknya ke jenjang yang lebih tinggi. Kerapnya Pemerintah Purworejo memberikan pelatihan/sosialisasi berdampak pada peningkatan wawasan baru untuk masyarakat sekitar. Sehingga pola pikir masyarakat berorientasi ke arah kemajuan. Peningkatan pengunjung pasca perbaikan sarana prasarana obyek wisata di Purworejo mampu meningkatkan 
pengunjung mancanegara maupun lokal dan mempengaruhi peningkatan pendapatan.

Pembangunan Bandara YIA juga berdampak negatif bagi masyarakat Jogoboyo dan Dadirejo sebagai wilayah perbatasan. Yaitu tingkat kriminalitas yang tinggi seperti penipuan yang dilakukan oleh para pekerja bandara YIA kepada penjual makanan. Selain itu, banyaknya pendatang baru yang kontrak/kost di Jogoboyo tidak dapat di data keluar masuknya. Hal tersebut berdampak pada susah membedakan penduduk asli dan pendatang di Jogoboyo. Hal tersebut dimanfaatkan oleh daerah lain untuk melakukan tindak pencurian di Desa Jogoboyo. Harga tanah yang tinggi juga berakibat pada mafia tanah dan sengketa tanah yang tidak kunjung selesai. Selain itu, dampak negatif yang di dapatkan adanya bandara Internasional Yogyakarta juga pengeluaran yang semakin bertambah. Pengeluaran tersebut disebabkan oleh masyarakat yang membangun usaha, juga biaya pendidikan, dan harga pajak tanah yang meningkat di kawasan Purwodadi dan Bagelen.

\section{Ucapan Terima Kasih}

Terima kasih kepada semua pihak yang terlibat dalam penulisan penelitisn ini sehingga dapat dilaksanakan dengan baik, serta kepada tim redaksi Jurnal Dimensia
Pendidikan Sosiologi UNY yang telah menerbitkan karya ini.

\section{Daftar Pustaka}

Agung, B. (2018, November 08). Radar Jogja. Retrieved from https://radarjogja.jawapos.com/20 18/11/08/infrastruktur-jadiprioritas-dukung-kegiatanstrategis-nasional

Budiman, A. (2000). Teori Pembangunan Dunia Ketiga. Jakarta: Gramedia.

Chang, Y.-C. (2010). The Development Of Regional Airports In Asia. WIT Transactions on State of the Art in Science and Engineering, 38.

Dewantara, J. R. (2019, Maret 13). Jogjapolitan. Retrieved from https://m.harianjogja.com/jogjapolit an/2019/03/13/kulomprogogandeng-purworejo-tangani-efeknyia

Fakih, D. M. (2002). Runtuhnya Teori Pembangunan dan Globalisasi. Yogyakarta: Insist Press.

Heksantoro, R. (2018, Maret 23). detikNews. Retrieved from https://m.detik.com/news/beritajawa-tengah/ada-bandara-dikulon-progo-investor-asing-lirikpurworejo

Huberman, M. B. (2009). Analisis Data Kualitatif Buku Sumber Tentang Metode-Metode Baru. Jakarta: UI Press.

Kasarda, J., \& Lindsay, G. (2011). Aerotopolis. "The Way We'll Live Next. New York: Farrar, Straus and Giroux.

Moleong, L. (2014). Metodologi Penelitian kualitatif. Bandung: Remaja Rosdakarya

Publik, B. K. (2017, Januari 2017). Kementerian Perhubungan Republik Indonesia. Retrieved from dephub.go.id/post/read/pembangu nan-bandara-internasionalyogyakarta-di-kulon-progo-resmidimulai

Putry Ayu Aryany, W. P. (2014).

Perubahan Penggunaan Lahan

di Kawasan Sekitar Bukit 


\author{
Semarang Baru. Jurnal \\ Teknik PWK, 3.
}

Salindri Kusumawati, K. N. (2016, Juli). Pengaruh Perkembangan Bandara

Internasional Adi Soemarmo

Terhadap Perubahan Lahan di

Sekitarnya. region, 7, 82.

Saputra, I. Y. (2018, November 3). Semarang Pos.com. Retrieved from

https://news.harianjogja.com/read/ 2018/11/03/500/950143/dekatdengan-purworejo-bandarakulonprogo-bakal-untungkan-jawatengah

Shahab, K. (2013). Sosiologi Perdesaan. Jogjakarta: Ar-Ruzz Media.

Soekanto, S. (2012). Sosiologi Suatu Pengantar. Jakarta: Raja Grafindo Persada.

Soetomo. (2006). Strategi-strategi Pembangunan Masyarakat. Yogyakarta: Pustaka Pelajar.

Sugiyono. (2013). Metode Penelitian Kuantitatif Kualitatif dan R\&D. Bandung: Alfabeta.

Sumarwan, U. (2004). Perilaku Konsumen Teori dan Penerapannya dalam Pemasaran. Bogor: Ghalia Indonesia.

Suryani. (2008). Perilaku Konsumen. Yogyakarta: Graha IImu.

Susanto, A. S. (1995). Sosiologi Pembangunan. Bimacipta

Yosodipuro, B. (2018, Juli 23). Obyektif.com. Retrieved from https://obyektif.com/kulonprogodan-purworejo-mulai-promosikanbandara-nyia.html

Yunus, H. (2011). Manajemen Kota Perspektif Spasial. Yogyakarta: Pustaka Pelajar.

Zulfikar, W. (2017). Dampak Sosial, Ekonomi Dan Politis Dalam Pembangunan Bandara Udara Kertajati Di Kabupaten Majalengka. Jurnal Caraka Prabu, 01, 59. 